https://doi.org/10.26593/jihi.v17i1.3532.139-152

\title{
Analisis Dimensi Internasional Konflik Papua dalam Model Counterinsurgency (COIN)
}

\author{
Muhammad Angga Ramdhan ${ }^{1}$ \\ ${ }^{1}$ Indigenous Corporate Training Inc, Canada, M.anggaramdhan@gmail.com
}

\begin{abstract}
ABSTRAK
Model berlian counter-insurgency oleh McCormick merupakan kerangka teori umum strategi militer Indonesia menumpas gerakan insurgensi Papua. Tulisan ini menawarkan makna baru dalam menginterpretasi model COIN dengan memfokuskan ke lensa studi konflik dan hubungan internasional. Untuk mencapai tujuan tersebut, tulisan ini menggunakan metode kualitatif studi literatur untuk menjelaskan mengapa internasionalisasi isu Papua yang tidak terselesaikan akan menghalangi usaha pemerintah Indonesia untuk memenangkan perang dengan insurgensi Papua.. Hasil dari analisis mengidentifikasi jika pengaplikasian strategi COIN McCormick secara sempit tidak hanya gagal dalam menyesaikan konflik Papua, tapi juga memberi ruang terbentuknya dinamika baru dalam dimensi internasionalnya, sehingga perlu adanya interpretasi baru terhadap model COIN di Papua, yaitu dengan memberikan solusi terhadap eliminasi akar konflik ketimbang eliminasi total dengan militer.
\end{abstract}

Kata kunci: Counter-insurgency, Papua, konflik, internasionalisasi.

\section{ABSTRACT}

McCormick counter-insurgency diamond model is general theoretical framework to describe Indonesia's military strategy in quelling Papuan insurgencies. The paper offers new meaning in interpreting the model by focusing on the lens of conflict and international relations studies. To achieve its purpose, this paper use qualitative method of literature study to explain why the internationalization of unresolved Papuan issues can hinder Indonesian government efforts to win the war against Papuan insurgencies. The results shown in the analysis identified that the aplication of McCormick model in limited definition is not only failed to solve Papuan conflict, but also create new dyamics in its international dimension. Therefore, new interpretation of the model for the Papuan conflict is needed by providing solution to eliminate roots of conflict rather than total elimination to the insurgent by military.

Keywords: Counter-insurgency, Papua, conflict, internationalization.

\section{A. Latar Belakang}

Penyelesaian militer, khususnya strategi counter-insurgency berbasis model berlian McCormick, menjadi acuan untuk menyelesaikan isu keamanan dalam konflik internal antara pemerintah Indonesia dengan kelompok pro-kemerdekaan Papua. Operasioperasi militer tersebut masih bisa menahan konflik Papua dalam skala lokal dan menghindari eskalasi konflik Papua menjadi high-intensity conflict. Namun, beberapa perkembangan dalam periode empat tahun terakhir di konflik Papua perlu mendapat perhatian khusus.

Perkembangan yang masih mengkhawatirkan terlihat dalam beberapa kasus kekerasan yang terjadi. Pada 1 Desember 2018, Tentara Pembebasan Nasional Papua Barat (TPNPB) dan Organisasi Papua Merdeka (OPM) menembak mati 19 pengawai Istaka Karya di kabupaten Nduga, dan merupakan peristiwa kekerasan paling mematikan di Papua pada tahun 2018. Peristiwa lain yang mempunyai magnitudo sama dengan penembakan Nduga terjadi di Biak 
pada 6 Juli 1998, Wamena pada 4 April 2003, dan Paniai pada 2014. Peristiwa Biak terjadi ketika sekelompok pendukung Organisasi Papua Merdeka mengibarkan bendera Bintang Kejora secara damai. Aparat keamanan merespon dengan operasi militer. Akibatnya, 8 orang meninggal dunia, 3 orang dinyatakan hilang, 37 orang terluka, 150 orang ditahan, dan 32 tubuh tidak teridentifikasi. ${ }^{1}$ Sedangkan dalam peristiwa 'Wamena Berdarah', penyerangan terhadap markas Kodim 1702/Wamena menjadi pemicu operasi penyisiran di 25 kampung. Penyerangan itu menyebabkan dua anggota Kodim kehilangan nyawanya, yaitu Lettu TNI AD Napitupulu dan Prajurit Ruben Kana Satu orang juga mengalami luka berat. ${ }^{2}$ Berdasarkan data Komnas HAM, kasus ini menyebabkan sembilan orang tewas, serta 38 orang luka berat. Selain itu pemindahan paksa terhadap warga 25 kampung menyebabkan 42 orang meninggal dunia karena kelaparan, serta 15 orang korban penganiayaan secara sewenang-wenang. Komnas HAM juga menemukan pemaksaan penandatanganan surat pernyataan, serta perusakan fasilitas umum. ${ }^{3}$ Contoh ketiga adalah penembakan di Enrotali, kabupaten Paniai, yang menewaskan 4 remaja dan melukai 17 orang lainnya. Komnas HAM menemukan bahwa ada pelanggaran HAM berat dalam penembakan Paniai.

Siklus kekerasan Papua tak terbatas dalam konflik bersenjata. Peristiwa rasisme terhadap mahasiswa asal Papua di Surabaya pada Agustus 2019, misalnya, telah memicu kerusuhan massal di Paniai, Fak-Fak, Sorong dan terakhir di Wamena. Dalam peristiwa kerusuhan tersebut, 6 warga sipil dan 1 tentara dilaporkan

\footnotetext{
${ }^{1}$ Afriandi Djon, The Indonesia COIN strategy: failures and alternative approaches in overcoming the Papuan insurgency. Naval Post Graduate School. 2015.

${ }^{2}$ Mehulika Sitepu, Bagaimana Kronologi tiga kasus pelanggaran HAM berat di Papua. 2017.

${ }^{3}$ Tempo, Komnas HAM Temukan Pelanggaran Berat di Papua, Disadur dari:

https://nasional.tempo.co/read/47417/komnas-hamtemukan-pelanggaran-ham-berat-di-papua. Diakses pada: 4 Maret 2019, 18:37 WIB.
}

menjadi korban. Namun Polri membantah laporan tersebut. ${ }^{4}$ Konfirmasi jumlah korban mengalami kendala karena pemerintah Indonesia menutup akses jurnalis dan internet saat kerusuhan Papua berlangsung.

Ketertutupan Pemerintah Indonesia dalam operasi counter-insurgency, terutama soal kekerasan dalam penanganan konflik, juga mengundang perhatian dari negara-negara pasifik seperti Vanuatu dan Kepulauan Solomon di perdebatan umum PBB pada tahun 2016. Narasi kekerasan juga menjadi landasan utama mengapa organisasi seperti United Liberation Movement of West Papua (ULMWP) yang mendukung kemerdekaan Papua mendapat dukungan politis dari beberapa organisasi HAM internasional dan politisi dari Vanuatu dan kepulauan Solomon. Meskipun negara kepulauan pasifik seperti Vanuatu dan Kepulauan Solomon mempunyai kekuatan kecil dalam mempengaruhi konstelasi internasional, tuduhan diplomatik dalam perdebatan PBB tentu bisa merusak imej baik pemerintah Indonesia di kancah internasional.

Dari sini muncul pertanyaan; mengapa konflik yang seharusnya menjadi masalah domestik di Indonesia bisa mendapat perhatian komunitas internasional dan negara-negara kepulauan pasifik? Apakah ada korelasi dalam strategi penanganan counter-insurgency di Papua dengan pembentukan dimensi internasional yang kini berlangsung dalam dinamika konflik Papua? Tulisan ini kemudian mencoba membedah korelasi antara strategi counter-insurgency konflik Papua dan dimensi internasional saat ini dalam konflik Papua, khususnya dalam pembentukan interest negara-negara pasifik ke penanganan konflik Papua, dengan

\footnotetext{
${ }^{4}$ Febriana Firdaus, West Papuan Protesters Killed by Indonesian Police: Witnesses. AlJazeera. 28 Agustus 2019. Disadur dari:

https:/www.aljazeera.com/news/2019/08/west-papuanprotesters-killed-indonesian-police-witnesses190828103919896.html
} 
menginterpretasi strategi counter-insurgency dalam lensa studi konflik.

\section{Kajian Pustaka}

Tulisan mengintrepatisi kembali metode counterinsurgency oleh Afriandi Djon dalam thesis berjudul The Indonesia COIN strategy: failures and alternative approaches in overcoming the Papuan insurgency (2015). Dalam penelitiannya, Djon berargumen bahwa efektifitas operasi penumpasan insurgensi terhambat oleh gagalnya TNI merangkul dukungan masyarakat lokal. Beberapa contoh seperti di Paniai, Puncak Wijaya, dan Nduga, menunjukkan peran masyarakat lokal dalam menyembunyikan insurgen dari kejaran aparat keamanan. Perlakuan kasar aparat keamanan terhadap masyarakat lokal juga membuat mereka bersimpati terhadap ide kemerdekaan Papua. Sehingga, ketika operasi militer berlangsung, warga sipil seringkali menjadi korban. pola-pola peristiwa ini mengundang reaksi dari organisasi internasional seperti Human Right Watch. Atas dasar temuan tersebut, Djon menyimpulkan penyertaan aspek budaya-sosial dalam pendekatan militer menjadi alternatif penting untuk mengalahkan gerakan insurgensi Papua. ${ }^{5}$

Merujuk penemuan tersebut, tulisan ini melihat bahwa ada permasalahan lain yang terbentuk; yakni bagaimana penanganan dengan dominasi militer membuat konflik ini mendapat perhatian komunitas internasional, khususnya negara-negara Pasifik. Dalam tulisan ini, penulis membangun argumen bahwa kekerasan militer memberi ruang manuver politik bagi aktor luar untuk mengkritik pemerintah Indonesia. Khususnya tuduhan dalam pelanggaran Hak Asasi Manusia (HAM). Manuver politik ini mendapat legitimasi karena HAM pada dasarnya telah menjadi norma yang diterima secara luas dalam hubungan antar-bangsa. Dengan kata lain, penyelesaian konflik dengan total military, dimana militer mendapat justifikasi untuk melakukan kekerasan, akan menimbulkan potensi internasionalisasi dalam konflik lokal. Inilah logika dasar mengapa dalam aktor internasional menjadi bagian analisis dalam diamond model counter insurgency.

Perhatian negara Pasifik terhadap dinamika kekerasan konflik Papua serta korelasinya dengan analisis aktor internasional dalam model McCormick menjadi impetus tulisan ini, yakni pentingnya interpretasi ulang terhadap model militer dalam penanganan konflik Papua menjadi penting. Tulisan ini mencoba memberi kontribusi dalam interpretasi ulang tersebut, yakni dengan menggunakan kebijaksaan (wisdom) yang ada dalam studi hubungan internasional dan studi konflik dalam pengaplikasian strategi-strategi militer yang bersumber pada model McCormick.

${ }^{5}$ Djon, Op Cit, hal 61-73. 


\section{Diamond Model Counter Insurgency}

Konflik Papua dalam model McCormick adalah konflik antara Pemerintah Indonesia dengan kelompok insurgensi/separatis Papua. Definisi insurgensi adalah sebuah gerakan untuk menggulingkan otoritas pemerintah melalui perang terbatas dengan konfrontasi bersenjata. ${ }^{6}$ Taktik umum dari kelompok insurgensi adalah menyerang titik terlemah dari negara dengan menyembunyikan diri bersama masyarakat. Kelompok insurgensi menghindari konfrontasi langsung seperti perang skala besar karena keterbatasan kekuatan militer. Strategi ini membuat pendekatan tradisional tidak lagi efisien karena menumpas kelompok insurgensi menimbulkan korban terhadap masyarakat sipil. Tidak jarang, yang menjadi korban dari operasi penumpasan insurgensi oleh negara adalah warga negaranya sendiri.
Dari sini muncul konsep counter-insurgency (COIN), yakni strategi khusus penyelesaian insurgensi menggunakan gabungan komponen militer, paramiliter, politik, ekonomi, psikologi, dan aksi sipil. ${ }^{7}$ Definisi lain dari counterinsurgency adalah upaya pemerintah untuk mengalahkan gerakan insurgensi dengan kombinasi faktor militer, politik, ekonomi dan psikologi. $^{8} \quad$ Pusat strategi COIN adalah mendapatkan 'hati dan pikiran masyarakat'. Asumsi utamanya adalah sgerakan insurgensi akan mati bila mereka terputus dari dukungan masyarakat lokal. David Galula berpendapat jika formula COIN yang ideal terdiri dari 80 persen politik dan 20 persen militer. ${ }^{9}$

\section{Gambar 1. Model Berlian Counterinsurgency dalam Konflik Papua}

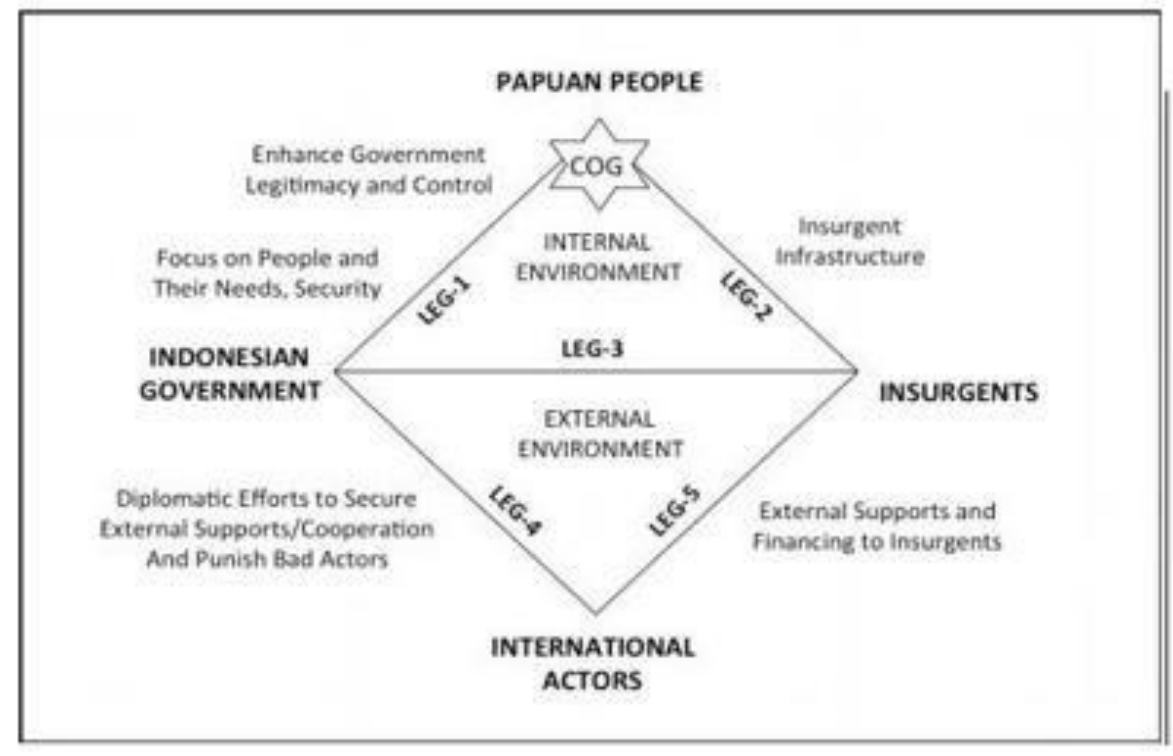

Sumber: Afriandi Djon, The Indonesian CON Strategy: Failures and Alternative Approaches in Overcoming the Papuan Insurgency, hal 27. 2015.

\footnotetext{
${ }^{6}$ United Kingdom, Ministry of Defence (2004), The Military Contribution to Peace Support Operation, hal 4.
}

\footnotetext{
${ }^{7}$ Ibid, hal 5.

${ }^{8}$ Paul D. Williams, Security Studies: An Introduction $2^{\text {nd }}$ eds, New York: Routledge. 2013 Hal 473.

${ }^{9}$ David Galula, Counterinsurgency Warfare: Theory and Practice, London: Praeger Security International. 2006.
} 
Alasan dari rasio ini karena kekuatan militer seharusnya digunakan untuk menjamin ruang untuk kesejahteraan, keamanan serta kemajuan politik sebuah masyarakat. Audrey Cronin turut mengembangkan pemikiran Galula dengan menawarkan 6 cara menyelesaikan konfrontasi dengan gerakan insurgensi: (1) tekanan dari negara, (2) negosiasi politik, (3) reformasi kebijakan ke arah penyelesaian damai ketimbang kekerasan militer, (4) hilangnya kepemimpinan dari insurgensi, (5) hilangnya dukungan publik untuk gerakan insurgensi, dan (6) tercapainya tujuan politik dari gerakan insurgensi. ${ }^{10}$

Empat (4) aspek penting dalam perang gerilya adalah pemerintah, populasi lokal, kelompok insurgensi dan aktor internasional. Dalam pengaplikasian model ini ke perang gerilya di Papua, masyarakat Papua menjadi centre of gravity (COG). Baik pemerintah Indonesia dan kelompok insurgensi seperti TPNPB/OPM berusaha menguasai posisi dan opini masyarakat Papua dalam perjuangan mereka. Djon, dalam analisisnya, mengatakan jika jalan untuk mengalahkan gerakan insurgensi (Leg 3) adalah memenuhi kebutuhan masyarakat Papua untuk mendapatkan legitimasi dan dukungan politik (Leg 1), lalu menghancurkan infrastruktur-infrastruktur yang menopang aktivitas insurgensi (Leg 2). ${ }^{11}$

Model ini menegaskan inti peperangan berada dalam lingkup internal, melihat posisi masyarakat Papua sebagai elemen terpenting bagi pihak pemerintah Indonesia dan kelompok insurgensi. Namun, potensi pihak luar untuk mengintervensi mungkin terjadi sehingga lingkungan eksternal mempunyai signifikansi tersendiri. Dalam skema ini, pemerintah Indonesia harus mengupayakan diplomasi untuk mendapatkan legitimasi dan kooperasi komunitas

\footnotetext{
${ }^{10}$ Audrey Kurth Cronin, How Terrorism Ends: Understanding the Decline and Demise of Terrorist Campaigns Princeton, New Jersey: Princeton University Press. 2009.

${ }^{11}$ Djon, Op Cit, hal. 28.
}

internasional (Leg 4). Dua hal ini berguna untuk menggambarkan pihak insurgensi Papua sebagai 'musuh'. Imbasnya, potensi kelompok insurgensi Papua untuk mendapatkan legitimasi dan bantuan internasional akan tertutup.

\section{Dimensi Internasional dalam Konflik Internal}

Fungsi model strategi COIN bertujuan untuk menumpas insurgensi. Namun, insurgensi masih terjadi di Papua, bahkan mendapat dukungan diplomatik dari negara-negara Pasifik. Padahal dalam strategi McCormick legitimasi internasional menjadi kunci dalam menghalangi upaya insurgensi dan separatisme di Papua. Secara teoritis, hal ini karena aplikasi strategi COIN berdasar pada definisi yang sempit, yakni perang yang bertumpu antara insurgen dan pemerintah, dimana tujuan utamanya itu adalah memenangkan hati dan masyarakat. Selain itu, meski model McCormick dalam aplikasinya ke konflik Papua menegaskan pentingnya legitimasi internasional untuk menumpas insurgensi Papua, model tersebut tidak menjelaskan asumsi dasar mengapa sebuah konflik sampai bisa mendapat perhatian aktor internasional, atau dalam hal ini internasionalisasi konflik. Dari sini, literaturliteratur dari studi konflik dan hubungan internasional menawarkan interpretasi baru dalam model berlian McCormick di konflik Papua. Studi hubungan internasional, khususnya yang terfokus pada internasionalisasi konflik, juga menawarkan penjelasan mengapa sebuah konflik bisa mempunyai dimensi internasional. Literatur yang paling berpengaruh adalah Michael Brown, The internasional Dimension of Internal Conflict (1996).

Bagaimana studi konflik melihat konflik Papua, dan bagaimana dimensi internasional dalam konflik terbentuk? Mengacu pada Brown, konflik Papua adalah konflik internal, didefinisikan sebagai unjuk pertarungan politis dengan potensi kekerasan akut, yang sumbernya berasal dari faktor domestik daripada sistem 
internasional. ${ }^{12}$ Kekerasan menggunakan senjata umumnya menyertai perkembangan dalam konflik ini. Ruang lingkup dari konflik internal berada dalam batas satu negara saja, namun mempunyai peluang melebar ke lingkup regional (spillover). ${ }^{13}$ Konflik internal menjadi fenomena terkemuka karena empat hal: (1) Konflik internal bisa menyebar, (2) konflik internal penting karena potensi melahirkan korban jiwa dengan jumlah besar (3) konflik internal bisa mempengaruhi dan mengundang intervensi negara lain, seperti menghasilkan arus pengungsi akibat konlik, dan (4) komunitas internasional mulai memperhatikan kaitan konflik internal dengan stabilitas global.

Studi komparatif konflik internal di berbagai belahan dunia oleh Michael Brown menyatakan jika konflik internal terjadi karena adanya pelemahan kapabilitas negara dalam menghadapi permasalahan domestik. Faktor struktural, politik, ekonomi, dan budaya menjadi kategori utama dalam kerangka analisis. Akademisi harus bisa mengidentifikasi mana yang menjadi faktor dasar (underlying causes) dan mana yang menjadi faktor pemicu (triggering factor) dalam empat faktor tersebut. Brown memberi konklusi jika pemimpin yang buruk (bad leaders) selalu menjadi pemicu utama sebuah konflik internal, disusul oleh pemerintahan yang buruk sehingga menimbulkan eskalasi dalam permasalahan domestik (bad domestic problem). Konflik internal mempunyai dimensi internasional ketika negara tetangga atau negara superpower memutuskan untuk ikut mengintervensi. Dan umumnya, intervensi tersebut seringkali membuat eskalasi daripada menyelesaikan konflik. Ketika intervensi negara lain berperan dalam eskalasi konflik, maka negara itu dikategorikan sebagai 'tetangga yang buruk' (bad neighbor).

\footnotetext{
${ }^{12}$ Michael Brown, The International Dimension of Internal Conflict. MIT Press: Cambridge, Massachuchets. 1996.

${ }^{13}$ Ibid, hal. 3-8.
}

Ada beberapa alasan mengapa negara tetangga memilih untuk mengintervensi konflik internasional. Pertama, negara mengintervensi dengan alasan kemanusiaan; yakni untuk mengembalikan stabilitas regional dan meredakan kerusakan akibat konflik. Kebijakan ini terkenal dengan istilah intervensi kemanusiaan. Namun, Brown menegaskan bahwa intervensi kemanusiaan dalam sejarah konflik internal tidak bebas dari kepentingan nasional. Berbagai alasan seperti memitigasi arus pengungsi, menjamin keamanan perbatasan, sampai mengambil keuntungan dan mempengaruhi negara yang sedang dilanda konflik internal atas aspek strategi kebijakan luar negeri.

Literatur lain oleh Gleditsch et al melihat bila negara mengintervensi sebuah konflik internal karena lima hal: (1) proxy war dengan menggunakan kelompok insurgensi dengan tujuan melemahkan negara lain, (2) intervensi dengan mendukung kelompok insurgensi untuk mengganti rezim pemerintahan yang tidak disukai, (3) negara lain mendukung konflik internal terjadi karena perebutan daerah di perbatasan, umum terjadi bila konflik internal berkaitan dengan isu insurgensi, (4) intervensi untuk melindungi etnis yang sama, dan (5) intervensi tit-for-tat, sebagai retaliasi bilamana negara yang diintervensi pernah menganggu stabilitas negara pengintervensi. ${ }^{14}$

Teori dan asumsi intervensi negara berguna untuk menginterpretasi motif negaranegara yang mempunyai minat terhadap konflik Papua. Khususnya, teori ini menjadi acuan dalam membahas motif Vanuatu dan Kepulauan Solomon, negara pendukung insurgensi di Papua, dalam menyuarakan kepentingan ULMWP di komunitas internasional yang

\footnotetext{
${ }^{14}$ Kristian Skrede Gleditsch, Idean Salehyan, dan Kenneth Schultz. How Civil Wars Lead to International Disputes. Journal of Conflict Resolution, 52 (4). 2008.
} 
menjadi pemicu internasionalisasi konflik Papua dalam model COIN.

\section{Model Analisis Konflik Papua}

Analisis dari Lembaga Ilmu Pengetahuan Indonesia (LIPI) dalam Papua Road Map (PRM) merupakan acuan utama ketika berbicara tentang akar konflik Papua (lihat gambar 2). Literatur ini juga menjadi penting ketika berbicara tentang interpretasi baru dalam model McCormick untuk konflik Papua. Dalam analisisnya, empat isu menjadi sumber utama konflik Papua, yakni: (1) Marginalisasi dan diskriminasi terhadap masyrakat asli Papua, (2) kegagalan pembangunan ekonomi yang tidak menyertakan aspek sosial-budaya, (3) kekerasan dan pelanggaran HAM oleh negara, dan (4) Perbedaan persepsi dalam konstruksi sejarah pengintegrasian Papua ke Indonesia pada tahun 1969. ${ }^{15}$ Secara spesifik, PRM menjadi acuan utama untuk analisis konflik Papua.
Meskipun ada variasi pembingkaian masalah atau identifikasi faktor pemicu dalam berbagai literatur, sejauh ini muatan inti dari berbagai pemikiran selalu mengerucut pada empat sumber konflik rumusan PRM. ${ }^{16}$

\section{Metodologi Penelitian}

Tulisan ini menggunakan metodologi penelitian kualitatif dengan alasan untuk mencari pemahaman baru dalam aplikasi model COIN di konflik Papua. Selain itu, penambahan model Papua Road Map dalam pembahasan juga berguna untuk memperdalam makna dari lingkup eksternal dalam model COIN. Penelitian kualitatif menjadi ideal mengingat penemuan makna baru membutuhkan metode yang menekankan interpretasi humanistik terhadap makna, sesuatu yang umumnya berada dalam ranah metode-metode kualitatif. ${ }^{17}$

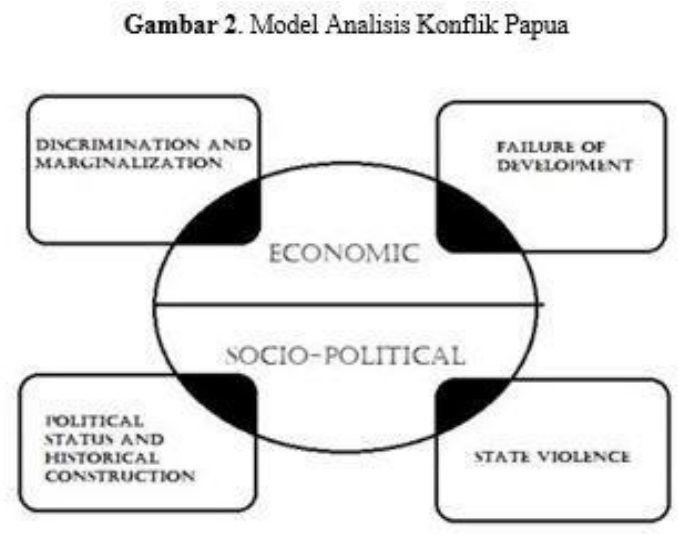

Sumber: Muridan S. Widjojo, Adriana Elisabeth, Amiruddin, Cahyo Pamungkas, Rosita Dewi Papua Road Map: Negotiating the past, improving the present, and securing the future. Jakarta: Lembaga Ilmu Pengetahuan Indonesia. 2008 .

${ }^{15}$ Muridan et al, Op Cit, hal. 10.

${ }^{16}$ Bandingkan dengan kompilasi isu Papua dalam Al Araf et al, Oase Gagasan Papua Bermartabat, Jakarta: Imparsial.2017.

${ }^{17}$ John W. Cresswell dan Cherl N. Poth. Qualitative Inquiry \& Research Design: Choosing among Five Approaches $\left(4^{\text {th }}\right.$ eds). London: Sage Publication. 2018. 
Penggunaan metode analisis konten menjadi pilihan dalam menganalisis aplikasi model COIN di konflik Papua. Data sekunder diambil dari literatur berupa buku, jurnal, koran, dan publikasi penelitian yang spesifik terpusat membahas Papua dari sisi studi konflik. Tulisan ini juga mengambil data dari wawancara yang dilakukan oleh peneliti lain. Kompilasi literatur tersebut akan dianalis secara induktif dan menjadi acuan penting interpretasi tulisan ini terhadap aplikasi model COIN dalam konflik Papua.

\section{Diskusi dan Hasil}

\section{Inti Konflik Papua}

Definisi McCormick menjelaskan bahwa konflik Papua adalah perang bersenjata antara pemerintah Indonesia dan insurgen atau kelompok separatis Papua, dimana dua pihak ini berupaya untuk memanfaatkan peran masyarakat Papua dan aktor internasional untuk memenangkan konflik. Berangkat dari pemahaman ini, Djon dalam tulisannya memberikan solusi secara garis besar untuk ,memenangkan konflik melawan insurgensi; (1) memperkuat legitimasi pemerintah dan kontrol keamanan (2) memfokuskan pada kebutuhan dasar masyarakat Papua, (3) menghancurkan infrakstruktur para insurgen, (4) mendapatkan legitimasi dari aktor internasional dalam penumpasan insurgensi, yang secara bersamaan menutup bantuan internasional untuk kelompok insurgen, baik yang bersifat material ataupun normatif. Definisi ini memfokuskan bahwa konflik adalah perang. Sehingga pengaplikasian model konfliknya dalam konflik Papua menjadi militeristik.

Sedangkan bila melihat dari lensa studi konflik internal yang dicetuskan oleh Brown, inti konflik Papua bukan perang separatisme, melainkan adanya kegagalan negara, baik berupa kepemimpinan yang buruk (bad leadership) atau permasalahan domestik akut yang tidak mampu diselesaikan oleh negara (bad domestic problem). Inti dari lensa ini adalah konflik Papua bukanlah perang antara pemerintah dan kelompok separatis pemerintah, melainkan adanya ketidakpuasan masyarakat Papua, baik secara politik, ekonomi, sejarah, bahkan kultur, yang mengakibatkan pemberontakan orang Papua terhadap pemerintah Indonesia.

Membanding definisi konflik Papua dari dua lensa ini melihatkan perbedaan yang signifikan. Model McCormick dalam menyelesaikan konflik Papua menitikberatkan eliminasi total terhadap kelompok insurgen. Sedangkan dalam lensa studi konflik, baik itu dari Brown ataupun LIPI, menegaskan bahwa Pemerintah Indonesia harus mempunyai solusi untuk menjawab akar permasalahan sosial, ekonomi, dan politik yang menyebabkan ketidakpuasan orang Papua sehingga mereka memilih pemberontakan. Faktor pemberontakannya yang harus dieliminasi, bukan pemberontaknya.

Meskipun secara teoritis berbeda, aplikasi praktisnya dalam mencapai tujuan inti mempunyai persamaan. Pada leg-1 dalam model McCormick, ditegaskan bahwa untuk mendapat hati dan perasaan masyarakat, perlu adanya upaya untuk menjamin kebutuhan dasar serta keamanan mereka. Bila kebutuhan dasar dan rasa aman terpenuhi, hal itu akan menumbuhkan legitimasi politik pemerintah terhadap masyarakat, sehingga pemerintah bisa mendapatkan kontrol yang kuat. Studi konflik internal menegaskan bahwa good governance dan kemampuan negara menjawab permasalah domestik menjadi inti menghindarkan negara dari konflik internal. Dua lensa ini kemudian mempunyai solusi yang sama dalam konflik Papua; kemakmuran orang-orangnya menjadi kunci perdamaian, baik dalam mengeliminasi insurgen ataupun konflik. 
Ini yang kemudian menjadi masalah sampai saat ini; dinamika kekerasan dalam konflik Papua lebih ditekankan dalam narasi ancaman nasional, bukan permasalahan domestik yang akut, sehingga pendekatan militeristik lebih ditekankan ketimbang pendekatan humanis. Dalam ekonomi misalnya, LIPI dalam Papua Road Map menekankan bahwa pengembangan ekonomi yang gagal menjadi salah satu akar konflik Salah satu permasalahan pelik adalah diskriminasi dan marjinalisasi di Papua yang berbentuk ketimpangan kapabilitas dalam bersaing antara pendatang dan masyarakat asli.

Meski secara statistik ekonomi Papua menunjukkan peningkatan: Indeks kemiskinan menurun dari 54,75 persen pada Maret 1999 menjadi 27,74 persen pada Maret 2018 (penurunan sebesar 27.11 persen) ${ }^{18}$ dan peningkatan Indeks Pengembangan Manusia (IPM) Papua merupakan tercepat di Indonesia: IPM provinsi Papua berada di 54,45 persen pada 2010 kemudian meningkat menjadi 59,09 persen pada 2018; IPM provinsi Papua Barat berada di 60,91 persen pada 2013 dan meningkat menjadi 62.29 persen pada 2017. Namun, bila dibandingkan dengan standar nasional kedua provinsi Papua masih berada di posisi bawah dalam IPM dan tingkat kemiskinan. Indikator lain, dari BPS seperti rasio Gini perdesaan ${ }^{19}$, menunjukkan bila ketimpangan ekonomi di Papua signifikan. Rasio gini perdesaan Indonesia berada di poin 0,324 pada September 2018, sedangkan provinsi Papua berada di poin 0,384 dan provinsi Papua Barat berada di poin 0,424. ${ }^{20}$ Mengapa ketimpangan ini terjadi? Keahlian dan

\footnotetext{
${ }^{18}$ Badan Pusat Statistik Provinsi Papua, Indikator Penting Provinsi Papua edisi Agustus 2018; Jayapura, 2018.

19 Indeks Gini mengukur tingkat deviasi dalam pendistribusian pendapat per individu atau rumah tangga dalam sebuah ekonomi dalam skala koefision 0 sampai 1. Indeks Gini dengan koefisien 0 merepresentasikan distribusi sempurna, sedangkan koefisien 1 merepresentasikan ketimpangan sempurna. Badan Pusat Statistik Provinsi Papua, Tingkat Ketimpangan Papua Barat Maret 2018 No. 39/07/Th. XII, 16 Juli 2018.

${ }^{20} \mathrm{Ibid}$
}

kapabilitas menjadi indikator utama dalam memenangkan persaingan dalam pasar pekerjaan. Dalam hal ini, migran yang datang ke Papua mempunyai keunggulan dalam hal kapabilitas dibanding penduduk asli Papua. Sehingga, persaingan menghasilkan ketimpangan secara periodik dalam bidang ekonomi.

Pendekatan militeristik juga membawa permasalahan tersendiri, yakni impunitas. Praktik impunitas dan lemahnya profesionalitas aparat keamanan sebetulnya menandakan ketidakhadiran negara di Tanah Papua. ${ }^{21}$ Impunitas juga yang kemudian menimbulkan situasi ketidakpercayaan dan permusuhan pada pemerintah Indonesia di Jakarta. Operasi-operasi militer yang seharusnya menjamin keamanan kemudian berubah menjadi sumber ketakutan untuk rakyat Papua. Tidak jarang justru penyerangan terhadap warga sipil dan aparatur keamanan merupakan reaksi balasan terhadap hard approach personil TNI atau Polri dalam pelaksanaan tugas untuk menjaga ketertiban masyarakat. Kelompok insurgensi memanfaatkan situasi tersebut untuk melegitimasi aksi-aksi penyerangan terhadap personil keamanan dan sebagai pembela rakyat Papua.

Impunitas dan pelanggaran HAM menjadi penghalang utama untuk mencapai dukungan masyarakat. Justifikasi nasionalisme serta keengganan pemerintah Indonesia untuk terbuka mengevaluasi performa militer membuat impunitas menjadi menghambat proses rekonsiliasi. Intransparansi Pemerintah tercermin dari simpang-siurnya data korban ataupun kebenaran dari pelanggaran HAM. Dari kompilasi kasus yang terhimpun dalam PRM, taksiran jumlah korban berkisar di angka 100.000 sampai 500.000. ${ }^{22}$ Beberapa sumber,

\footnotetext{
${ }^{21}$ Bandingkan argumen ini dengan Bobby Anderson, Papua Insecurities: State's Failure in The Indonesian Periphery. Hawaii: East-West Center. 2015.

${ }^{22}$ Muridan S. Widjojo, 'Non-State Actors and the 'Cycle' of Violence in Papua'. Presentasi di Workshop, Conflict, Violence and Displacement in Papua, Refugee Studies
} 
seperti dari Universitas Yale dari Amerika Serikat dan Sydney University dari Australia memberi rekomendasi bahwa konflik Papua layak masuk klasifikasi genosida. $^{23}$ Pembunuhan, penahanan tanpa proses hukum, dan penyiksaan terhadap penduduk asli berlangsung secara sistematis. ${ }^{24}$ Beberapa kasus pembunuhan terhadap tokoh Papua memperkuat statemen ini; pembunuhan Arnold Ap, pemusik, antropolog, dan tokoh lokal pada tahun 1989; Pembunuhan Theys Eluay, ketua dewan presidium Papua pada tahun 2001. Dua tokoh lain, Ketua OPM Kelly Kwalik meninggal oleh serangan militer pada 2009; dan Mako Tabuni, wakil ketua Komite Nasional Papua Barat (KNPB) pada tahun 2012.

Contoh-contoh kasus ini yang menjadi gambaran mengapa strategi COIN ini tidak menyelesaikan konflik Papua; Negara tidak hadir dalam menjamin kemakmuran dan keamanan masyarakat Papua, baik secara politik, ekonomi, dan sosiokultural, ditambah dengan proteksi negara terhadap oknum-oknum militer bermasalah, membuat operasi penumpasan insurgensi dianggap sebagai upaya kolonialisasi terhadap masyarakat Papua. Selama faktor-faktor bad domestic problem ini tidak teratasi, dinamika kekerasan Papua akan terus berlanjut.

\section{Dimensi Internasional Konflik Papua}

Dimensi internasional dalam konflik Papua terjadi karena tiga hal: (1) tidak terselesaikannya permasalahan domestik dalam konflik Papua, terutama soal rasa keadilan, ketimpangan ekonomi, dan impunitas. (2) adanya koneksi antara aktor insurgensi dengan dunia internasional, serta (3) adanya narasi diplomatik yang melegitimasi perjuangan insurgensi Papua

Centre (RSC), St Anthony College, Oxford, 26 October 2006.

${ }^{23}$ Muridan et al, Op Cit. hal 3.

${ }^{24} \mathrm{Jim}$ Elmslie dan Camillia Webb-Gannon, A Slow Motion of Genocide: Indonesia Rule on West Papua. Griffith Journal of Human Law and Dignity. Volume 1 No.2. 2013. Hal 142-166. dan secara bersamaan melemahkan legitimasi operasi COIN pemerintah Indonesia di Papua.

United Liberation Movement for West Papua (ULMWP) menjadi salah satu organisasi utama yang mendukung upaya insurgensi Papua. Konflik berkelanjutan membuka peluang bagi kelompok insurgensi ini untuk berevolusi. Pada

7 Desember 2014, pertemuan antara Koalisi Pembebasan Nasional Papua Barat (WPNCL), Republik Federal Papua Barat (NRFPB), dan Parlemen Nasional Papua Barat (NPWP) menyatakan untuk bersatu di bawan naungan ULMWP di Port Villa, Vanuatu. Dalam deklarasinya, ULMWP bertekad untuk menjadi wadah utama dalam memobilisasi gerakan internasional. Tujuan utama dari mobilisasi tersebut untuk mendapatkan legitimasi dan dukungan internasional terhadap kemerdekaan Papua. Dalam pembentukan ULMWP, Vanuatu memainkan peranan penting menyatukan tiga organisasi tersebut menjadi wadah diaspora Papua.

ULMWP naik menjadi ancaman diplomatik bagi Indonesia setelah organisasi regional kepulauan Pasifik, yakni Melanesian Spearhead Group (MSG), memasukkan ULMWP sebagai observer. Manuver ULMWP ini memaksa Indonesia untuk mengarahkan kekuatan diplomatiknya ke region Oceania. Tidak hanya Indonesia, keberadaan ULMWP juga membuat faksionalisasi di dalam MSG. Fiji dan Papua Nugini mengakui kedaulatan Indonesia di Papua, namun Kepulauan Solomon dan Vanuatu tetap memperjuangkan nasib Papua, dan akhirnya menjadi bahan perdebatan dalam debat umum PBB ke-72 pada tahun 2016, debat umum PBB ke-73, dan juga dalam sidang komisioner hak asasi manusia PBB di Jenewa. Ini adalah kali pertama isu Papua muncul kembali ke lingkungan PBB setelah referendum 1969 berlangsung, dan indikasi pertama jika konflik Papua mulai masuk traksi awal internasionalisasi konflik internal. 
Mengapa konflik Papua memasuki ranah internasional? Pertama, diplomasi pemerintah Indonesia gagal menghalangi dukungan Vanuatu dan Kepulauan Solomon Papua sehingga ULMWP terbentuk. Tidak hanya itu, pemerintah Indonesia juga gagal menghalangi penerimaan ULMWP ke dalam MSG. Kedua, ULMWP sebagai organisasi mempunyai kapabilitas diplomatik untuk mengakses komunitas internasional. John Ondawane, Benny Wenda, Rex Rumakiek dan Octavianus Mote adalah tokoh diaspora Papua yang mempunyai koneksi luas ke negara-negara Melanesia, terutama Vanuatu. Benny Wenda menjadi corong utama setelah muncul di Ted Talks Sydney di Australia pada 2013 dan telvisi nasional Te Karere di Selandia Baru pada 2015. Selain itu, Benny Wenda juga muncul dalam televisi nasional Inggris Raya dan Kanada untuk memberi keterangan kerusuhan Wamena pada September 2019.

Pembiaran masalah domestik Papua, yakni impunitas dan diskriminasi ekonomi tanpa penyelesaian menjadi faktor kegagalan diplomasi Indonesia. Impunitas seringkali mengundang perhatian dari pemerhati HAM baik di negara ataupun organisasi internasional, namun pemerintah Indonesia menolak untuk transparan ataupun menunjukkan keseriusan dalam menyelesaikan masalah tersebut. Dalam aspek ekonomi, pemerintah Indonesia telah mengalokasikan 45 triliun rupiah dalam membangun Papua. ${ }^{25}$ Spesifik pada tahun 2013, APBD Papua mencapai 61 triliun rupiah, dengan dana tambahan OTSUS sebesar 33 triliun rupiah. $^{26}$ Argumen pembangunan ini juga menjadi landasan utama diplomat Indonesia menggunakan right of reply terhadap tuduhan

${ }^{25}$ Cahyo Pamungkas, Menggugat Proyek Pembangunan Perdamaian di Papua Barat setelah Reformasi 1998 di Oase Gagasan Papua Bermartabat, Imparsial, 2017. hal 287.

${ }^{26}$ Tito Karnavian, The Role of the National Police in Countering Insurgencies in Indonesia. Counter Terrorist: Trend and Analyses, 2017. hal 11.
Vanuatu dan Kepulauan Solomon. Namun, bantuan ekonomi tersebut tidak menyelesaikan ketimpangan kapabilitas ataupun kesejahteraan dibanding provinsi Indonesia lainnya, Tidak hanya itu, impunitas juga membuat perhatian internasional luput terhadap upaya pemerintahan Indonesia dalam mengembangkan kesejahteraan Papua.

ULMWP mempunyai kemampuan propaganda dalam internasionalisasi konflik Papua. Memanfaatkan lambannya pemerintahan Indonesia dalam menyelesaikan isu sosialekonomi dan budaya di Papua, ULMWP menggambarkan situasi tersebut sebagai bentuk kolonialisasi. Dalam deklarasi Westminster di parlemen Inggris pada 3 Mei 2016, ULMWP menekankan 5 poin yang menjadi kunci internasionalisasi isu Papua: (1) Pelanggaran HAM Papua yang terus berlanjut, (2) ancaman punahnya populasi Papua asli di tanahnya sendiri, (3) menegaskan kembali hak kemerdekaan untuk rakyat Papua, (4) menganggap Pepera 1969 telah merampas hak tersebut, (5) menuntut untuk referendum ulang dalam pengawasan PBB seperti yang tercantum dalam resolusi 1514 dan resolusi 1541. Deklarasi ini ditandatangani beberapa politisi dan perdana menteri, seperti perdana menteri Kepulauan Solomon Mannasseh Sovagare, menteri luar negeri Vanuatu Bruno Leignkone, dan perdana menteri Tonga Samuela Akilisi Pohiva ${ }^{27}$

Beberapa laporan NGO dan literatur akademik turut menguatkan gambaran kekerasan terhadap rakyat Papua. Seringkali delegasi Vanuatu ataupun Kepulauan Solomon menggunakan data dari laporan dan literatur akademik tersebut untuk menyerang Indonesia. Tuduhan pelanggaran HAM, seperti dalam pertemuan komisioner HAM PBB ke-34 pada 1 Maret 2017. Secara spesifik, anggota parlemen

\footnotetext{
${ }^{27}$ United Liberation Movement of West Papua, The Westminster Declaration, 2016. Disadur dari: https://www.ulmwp.org/westminster-declaration.
} 
Vanuatu Ronald Marshall menyebut penembakan di Wamena pada tahun 2003 dan Paniai pada tahun 2014 tidak pernah menemui penyelesaian ataupun pengadilan. ${ }^{28}$ Barret Salato, diplomat Kepulauan Solomon dalam komisioner HAM PBB turut menyinggung pelanggaran HAM oleh Indonesia di Papua dalam sidang komisioner PBB ke-39 pada tahun 2016. .Menurutnya laporan yang didapatkan delegasi kepulauan Solomon, 300 orang asli Papua ditahan tanpa alasan jelas selama periode Juli dan Agustus. Selain itu Kepulauan Solomon juga menyinggung tentang diskriminasi dan marjinalisasi orang Papua. ${ }^{29}$

Tidak adanya transparansi dan keterbukaan dari aparat keamanan di Papua menjadi faktor penghalang tunggal untuk mengaudit kebenaran laporan dan tuduhan dari diplomat Vanuatu dan Kepulauan Solomon. Meski Indonesia berulang-kali menyatakan pelanggaran HAM hanya berdasarkan propaganda ULMWP, komunitas internasional cenderung bersimpati terhadap nasib orang Papua. Rasa simpati pula yang menjelaskan landasan dasar kebijakan luar negeri Vanuatu dan Kepulauan Solomon untuk mengangkat isu HAM dan perjuangan ULMWP dalam komunitas internasional.

Dua alasan menjelaskan mengapa rasa simpati bisa menggerakkan Vanuatu dan Kepulauan Solomon untuk membantu ULMWP. Pertama, pelanggaran HAM menjadi magnet utama untuk negara memperhatikan sebuah konflik internal. Kedua adalah siapa korban dari pelanggaran HAM tersebut. Dalam kasus HAM di Papua, etnis Melanesia menjadi korban utama dari impunitas. Ikatan etnik Melanesia kemudian

${ }^{28}$ The Republic of Vanuatu Minister of Justice and Community Development, $34^{\text {th }}$ Session of the Human Rights Council, $1^{\text {st }}$ March 2017: Geneva, Switzerland. Statement disampaikan oleh Hon. Ronald K. Warsal. ${ }^{29}$ United Nation, OCHCR, 39th Regular Session Human Rights Council. 2016. Disadur dari:

https://www.ohchr.org/EN/HRBodies/HRC/RegularSession s/Session39/Pages/39RegularSession.aspx dijadikan alat propaganda ULMWP untuk melegitimasi dukungan dari negara luar. Vanuatu dan Kepulauan Solomon, negara mayoritas etnik Melanesia, kemudian menyambut propaganda ULMWP. Selain dengan alasan kekerabatan Melanesia (Melanesian Brotherhood), membantu ULMWP juga menjadi tanggung jawab moral untuk melindungi masyarakat Papua, yang dalam gambaran ULMWP merupakan orang-orang tertindas dalam kolonialisme Indonesia.

\section{Kesimpulan}

Pengaplikasian strategi COIN McCormick secara sempit tidak hanya gagal dalam menyesaikan konflik Papua, tapi juga memberi ruang terbentuknya dinamika baru dalam dimensi internasional di konfliknya. Operasi COIN di Papua tidak akan pernah berhasil bilamana kesejahteraan rakyat Papua masih terabaikan. Negara harus hadir sebagai pelindung masyarakat Papua. Tidak hanya untuk menyelesaikan konflik, kehadiran negara sebagai pelindung juga akan menutup legitimasi internasional terhadap insurgen Papua, terutama menutup manuver-manuver politik negara Pasifik terhadap sepak terjang ULMWP dalam arena diplomasi.

Tulisan ini juga menekankan bahwa filosofi dan pemaknaan dasar teoritis operasi COIN di Papua harus bergeser untuk menjawab tantangan-tantangan yang ada. Model McCormick di Papua seharusnya tidak terfokus pada praktek-praktek operasi untuk menumpas insurgensi, melainkan fokus pada upaya merangkul kembali para insurgen sebagai salah satu kesatuan dalam NKRI. Caranya adalah dengan menegaskan kembali komitmen negara untuk memenuhi kesejahteraan dan keamanan masyarakat Papua. Tulisan ini menyarankan bila menyelesaikan akar konflik menjadi strategi efektif untuk menghapus gerakan insurgensi Papua. 


\section{Referensi:}

Al-Rahab, Amiruddin. (2006). “Operasi-operasi militer di Papua: Pagar Makan Tanaman?", Jurnal Politik LIPI, 3(1). 3-23. Doi: 10.14203/jpp.v3i1.420

Ananta, Aris. Utami, Dwi Retno Wilujeng Wahyu dan Handayani, Nur Budi. (2016). "Statistics on Ethnic Diversity in The Land of Papua, Indonesia.". Asia and The Pacific Policy studies, 3(3), 458-474. Doi: 10.1002/app5.143.

Anderson, Bobby. (2015). Papua Insecurities: State's Failure in The Indonesian Periphery. Washington : East-West Center.

Badan Pusat Statistik. (2010). "Indonesia Census 2010”. Jakarta : Badan Pusat Statistik.

Badan Pusat Statistik Provinsi Papua. (2018). "Indikator Penting Provinsi Papua edisi Agustus 2018"; Jayapura: Badan Pusat Statistik

Badan Pusat Statistik Provinsi Papua Barat (2018), "Statistik Daerah Provinsi Papua Barat 2018". Manokwari: Badan Pusat Statistik.

Barash, David. P., \& Webel, Charles. (2003). Peace \& conflict studies. Thousand Oaks, CA: SAGE.

Brown, Michael. (1996). The International Dimension of Internal Conflict. Cambridge, Massachuchets: MIT Press.

Buzan, Buzan. Waever, Oli dan Wilde, Jaap. (1998). Security, A New Framework For Analysis. Boulder: Lynne Rienner

Council on Foreign Relations. (2019). "Syria Conflict: Global Conflict Tracker." https://www.cfr.org/interactive/global -conflict-tracker/conflict/civil-warsyria.

Council on Foreign Relations. (2019). "Ukraine Conflict: Global Conflict Tracker." https://www.cfr.org/interactive/global -conflict-tracker/conflict/conflictukraine.

Cresswell, John W. dan Poth, Cheryl N. (2018). Qualitative Inquiry \& Research Design: Choosing among Five Approaches (4th eds). London: Sage Publication.

Cronin, Audrey K,. (2009). How Terrorism Ends: Understanding the Decline and Demise of Terrorist Campaigns Princeton, New Jersey: Princeton University Press.

Djon, Afriandi. (2015). The Indonesia COIN Strategy: Failures and Alternative Approaches in Overcoming the Papuan Insurgency. Naval Post Graduate School.

Elmslie, Jim. dan Camillia Webb-Gannon. (2013). "A Slow Motion of Genocide: Indonesia Rule on West Papua.". Griffith Journal of Human Law and Dignity.1(2). 142-166.

Firdaus, Febriana. (2019). "West Papuan Protesters Killed by Indonesian Police: Witnesses." Al-Jazeera. https://www.aljazeera.com/news/2019 /08/west-papuan-protesters-killedindonesian-police-witnesses190828103919896.html. Diakses pada 1 September 2019.

Galula, David. (2006). Counterinsurgency Warfare: Theory and Practice, London: Praeger Security International. 
Gleditsch, Nils. P, Wallensteen, Peter., Eriksson, Mikael., Sollenberg, Margaretta., \& Strand, Havard. (2002). "Armed Conflict 1946-2001: A New Dataset." Journal of Peace Research, 39(5), 615-637. doi: $10.1177 / 0022343302039005007$.

Gleditsch, Kristian S., Salehyan, Idean dan Schultz, Kenneth. (2008). "How Civil Wars Lead to International Disputes." Journal of Conflict Resolution", 52(4). 479-506. Doi: $10.1177 / 0022002707313305$

Karnavian, Muhammad Tito. (2017). "The Role of the National Police in Countering Insurgencies in Indonesia." Counter Terrorist: Trend and Analyses. 9(9). 8-13.

Lamb, Kate. (2019). "An Earthquake: racism, rage and rising calls for freedom in Papua. Jayapura." The Guardian. https://www.theguardian.com/world/2 019/aug/31/an-earthquake-racismrage-and-rising-calls-for-freedom-inpapua. Diakses pada 4 September 2019.

Pamungkas, Cahyo. "Menggugat Proyek Pembangunan Perdamaian di Papua Barat setelah Reformasi 1998". Dalam Imparsial, (2017) Oase Gagasan Papua Bermartabat. Imparsial: Jakarta.

Saltford, John. (2003). The United Nation and the Indonesian Takeover of West Papua 1962-1969: Anatomy of Betrayal. RoutledgeCourzon: London
Sitepu, Mehulika. (2017). "Bagaimana Kronologi tiga kasus pelanggaran HAM berat di Papua." Tempo: https://nasional.tempo.co/read/47417/ komnas-ham-temukan-pelanggaranham-berat-di-papua. Diakses pada: 4 Maret 2019, 18:37 WIB.

The Republic of Vanuatu Minister of Justice and Community Development. (2017). $34^{\text {th }}$ Session of the Human Rights Council. 1 Maret 2017: Geneva, Switzerland.

The United Kingdom of Ministry of Defence. (2004). "The Military Contribution to Peace Support Operation". London: United Kingdom.

Widjojo, Muridan S. Elisabeth, Adriana. Amiruddin. Pamungkas, Cahyo. Dewi, Rosita. (2008). Papua Road Map: Negotiating the past, improving the present, and securing the future. Jakarta: Lembaga Ilmu Pengetahuan Indonesia.

. Widjojo, Muridan S. 'Non-State Actors and the 'Cycle' of Violence in Papua'. Tulisan tidak dipublikasikan.

Williams, Paul D, ed. Security Studies: An Introduction 2nd Eds, New York: Routledge.

United Nation, OCHCR, 39th Regular Session Human Rights Council. 2016. Disadur dari: https://www.ohchr.org/EN/HRBodies/ HRC/RegularSessions/Session39/Pag es/39RegularSession.as 